\title{
PREVALENCE AND RELATION OF URINARY TRACT INFECTION BACTERIAL PATHOGENS TO SEX AND AGES AMONG PATIENTS IN THREE ARAB COUNTRIES
}

\author{
Khaled Salah M. Azab ${ }^{1 *}$, Mohamed A. Abdel-Rahman ${ }^{1,}$, Hussien H. El-Sheikh, \\ ${ }^{1}$ Mohamed M.S. Farag \\ ${ }^{1}$ Botany and Microbiology Department, Faculty of Science, Al-Azhar University, \\ Cairo, Egypt
}

*Corresponding author: khaedsalah@azhar.edu.eg

\begin{abstract}
:
Background: urinary tract infections is one of the most prevalent bacterial infections worldwide. The present study aims to study and survey different isolates from urine specimens from different countries to assess their prevalence and their relation to urinary tract infections. One hundred and sixty-eight samples were randomly collected from three countries, Egypt, Sudan and Saudi Arabia, as follows: 43, 33 and 92, respectively. Samples were collected from private laboratories and from both sexes. The ages of the patients differed between three years and 89 years for females and from one year to 85 years for males between 4 / 2015-7 / 2016. All samples were inoculated on different selective and differential sterile culture media. After growth, isolated bacteria were identified by physiological and biochemical characteristic. Among all clinical samples, five bacterial genera were detected. The isolates were identified as Escherichia coli (93), Klebseilla spp. (32), Pseudomonas spp. (26), Proteus spp. (14), and Staphylococcus spp. (3). Regarding the sex of the patient, this study showed that females are more likely to be infected than males, with $53(31.55 \%)$ of the patients being males and 115 (68.45\%) of being females. The most common UTI bacterium was Escherichia coli, followed by Klebseilla spp. Majority of female infected cases were in menstruation age stage (14-44 years), while majority males were in old age stage (52-85 years). Surveys and studies of infectious factors are considered one of the most important epidemiological tools for tracking infectious diseases and predicting disease patterns, especially with regard to urinary tract infections due to their widespread prevalence and serious complications between the sexes at the global level.
\end{abstract}

Keywords: bacterial pathogens; urinary tract infections; clinical samples 


\section{Introduction:}

Urinary tract infections (UTIs) are known as microbial permeation of sterile urinary tract and is one of the most prevalent bacterial infections globally. It include infections of the urethra, bladder, ureters, and kidney (Barber et al., 2013). It is considered as a significant cause of morbidity in infant boys and in older men and women of all ages by causing serious consequences include recurrent infection, pyelonephritis with sepsis, kidney damage in young children, and premature birth (Flores-Mireles et al., 2015). UTIs in pregnant women are associated with an increased risk of maternal and neonatal illness and death, even when the infection without symptoms (Gilbert et al., 2013).

Various bacterial pathogens are responsible for UTI including Escherichia coli, Proteus spp., Klebsiella spp. and Staphylococcus spp. (Amdekar et al., 2011). Escherichia coli have been found to be the most common causative organism of UTI in many countries (Samra et al., 2005). Globally, E. coli is the most common pathogen causing UTIs, it causes $80-85 \%$ of cases (Abraham \& Miao, 2015, Tandogdu \& Wagenlehner, 2016).

Klebsiella pneumonia is the species of aerobic Gram-negative bacteria, it is the most relevant human pathogen within genus Klebsiella spp., and it is causing many infections worldwide including urinary tract and it is the most important microorganism causes urinary tract infection, next to Escherichia coli (Cristea et al., 2017) Peudomonas aeruginosa is an opportunist microbe and it is one of urinary tract infection microbes (Tumbarello et al., 2020). It is even the third most common pathogen-related with hospital-acquired catheter-associated UTIs (Jarvis \& Martone, 1992). Proteus mirabilis is also a frequently pathogen of the urinary tract, especially in patients undergoing long-term catheterization (Schaffer \& Pearson, 2015). The most common clinical appearance of Proteus infection is urinary tract infections and ninety percent of Proteus infections occur as a result of Proteus mirabilis (Jamil et al., 2019). Staphylococcus aureus is significantly isolated from urine samples obtained from longterm care patients (Muder et al., 2006).

Consequently, it is assumed that there will be a continuous follow-up to reveal the extent of these UTI pathogens and to see whether they are increasing or not by comparing recent results with the results of previous studies and to examine their prevalence among different countries. Therefore, this study aimed to isolate, identify and characterize of UTI bacterial pathogens from Egypt and surrounding countries Sudan and Saudi Arabia to assess their prevalence.

\section{Materials and Methods}

\section{Samples collection}

One hundred and sixty-eight samples were collected randomly from three countries, Egypt, Sudan and Saudi Arabia as the following 43, 33 and 92, respectively. The samples were collected from private laboratories and from two genders. The 
patients' ages were ranged from 3 years to 89 years in females and from one to 85 years in males, in the period between April 2015 to July 2016.

\section{Cultivation of samples}

The samples were transported safely into the private laboratory according to the microbial laboratory guide transfer (Cheesbrough, 2006). The samples were inoculated on various media by streaking technique; then incubated overnight at $37^{\circ} \mathrm{C}$. The cultured media for bacterial isolates were Cysteine-lactose-electrolyte-deficient agar (C.L.E.D) (Sandys, 1960), Muñoz et al., 1992); Sheep blood agar, (Spector, 1961); MacConkey agar (MacConkey, 1900), Chocolate agar (McLeod et al., 1927), and Thayer martin agar (Thayer \& Martin, 1964).

\section{Isolation and identification}

The obtained bacterial isolates have been secluded from pure colonies then scanned microscopically by using Gram stain method to differentiate between Gramnegative and Gram-positive bacteria (Coico, 2006). The identification experiments including the cultural, morphological, and physiological specifications of each isolate were done as previously described (Alfred \& Heidi, 2015). The biochemical tests utilized for isolates definition involved the following: catalase and coagulase tests; Novobiocine susceptibility; oxidase, indole, urease and citrate tests; lactose, glucose, and mannitol fermentation; and hydrogen sulfide test (Cheesbrough, 2006).

\section{Statistical analysis}

All data involved were evaluated statistically by the statistical package, IBM SPSS version 23.

\section{Results:}

The study included 168 urine samples that were collected from different countries, gender and ages. The samples have been distributed according to several considerations as follows:

\section{Samples distribution by countries}

A total of 168 samples have been collected to be examined were distributing among three countries, Egypt, Sudan and Saudi Arabia as following: 43, 33 and 92 samples, respectively (Fig.1).

\section{Distribution of samples according to gender.}

Out of total samples, $115(68.45 \%)$ were females and $53(31.55 \%)$ were males table (1) and (Fig.2). Regarding countries distribution, in Egyptian samples, 51.16\% were females and $48.84 \%$ were males. For Saudi Arabia, $84.78 \%$ of total samples were females and $15.22 \%$ were males. Whereas for Sudan samples, $45.45 \%$ were females and $54.55 \%$ were males (Fig. 3). 


\section{Identification and prevalence of isolates}

From the total identified isolates, E. coli were predominant with 93 strains (55.36\%), followed by Klebseilla spp. with 32 strains (19\%), Pseudomonas spp. with 26 strains (15.48\%), Proteus spp. with 14 strains (8.33\%) and Staphylococcus spp. with 3 strains (1.79\%) (Fig.4). The majority of isolated bacteria from Egypt were E. coli with 29 strains (67.44\%), followed by Pseudomonas spp. with 8 strains (18.6\%), Klebsiella spp. with 5 strains (11.63\%) and Staphylococcus spp. with one strain (2.33\%), while there is no Proteus spp. For Saudi Arabia, the most common were also E. coli with 48 strains (52.17\%), followed by Klebseilla spp. with 20 strains (21.74\%), Proteus spp. with 14 strains (15.22\%), Pseudomonas spp. with 8 strains (8.7\%) and Staphylococcus spp. with 2 strains $(2.17 \%)$. The most common isolates obtained from Sudan were also E. coli with 16 strains (48.48\%), followed by Pseudomonas spp. with 10 strains (30.3\%), and Klebsiella spp. with 7 strains (21.21\%), while Proteus spp. and Staphylococcus spp. were not detected in the examined clinical samples (Fig.5).

\section{Distribution of isolates between males and females}

The majority of isolates in female were E. coli $(58.26 \%)$, followed by Klebsiella spp. (22.61\%), Pseudomonas spp. (9.57\%), Proeus spp. (7.83\%) and Staphylococcus spp. (1.74\%), while in male were E. coli $(49.1 \%)$ followed by Pseudomonas spp. (28.3\%), Klebsiella spp. (11.32\%), Proteus spp. (9.4\%) and Staphylococcus spp. (1.89\%). (Fig.6)

\section{Cases distribution with regard to age stages}

According to female age stage, majority of the infected cases were in menstruation age stage (14-44 years) with $61.54 \%$, followed by menopause age stage (49-89) at $22.12 \%$ and Childhood stage (3-13 years) at $16.35 \%$ (Fig.7). On the Other hand, in males, old age stage (52-85 years) showed the majority infected cases with $54.1 \%$, followed by adult age stage (29-45) with $29.73 \%$ and Childhood stage (1-8 years) with $16.22 \%$ (Fig. 8).

Table (1): Urine samples distribution according to gender.

\begin{tabular}{|c|c|c|}
\hline Gender & Male & Female \\
\hline Sample count & 53 & 115 \\
\hline Sample percent & $31.55 \%$ & $68.45 \%$ \\
\hline
\end{tabular}




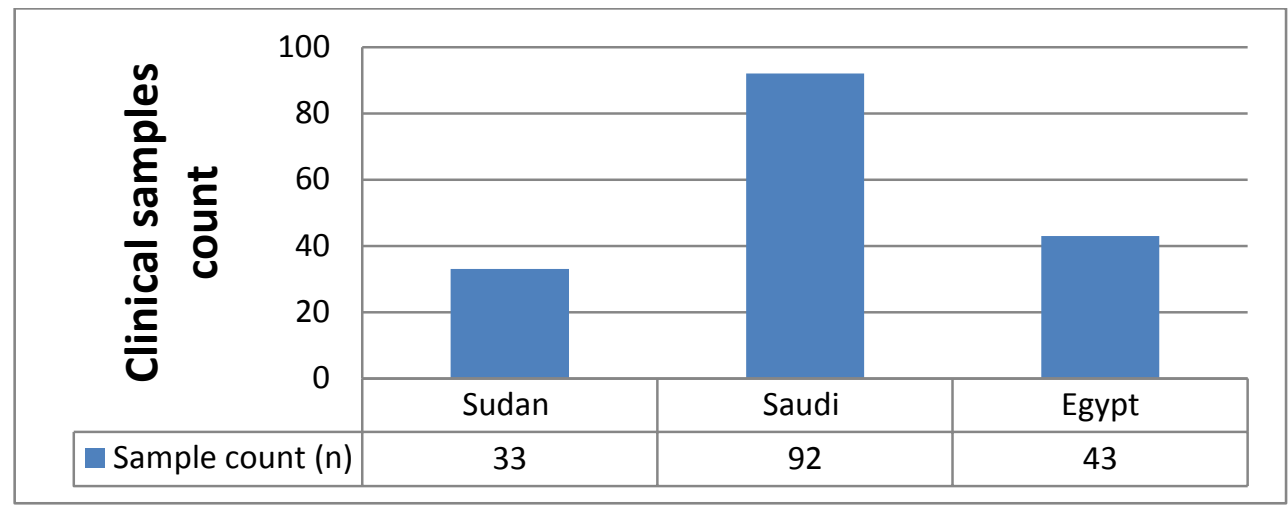

Fig (1): Total of samples distribution according to countries.

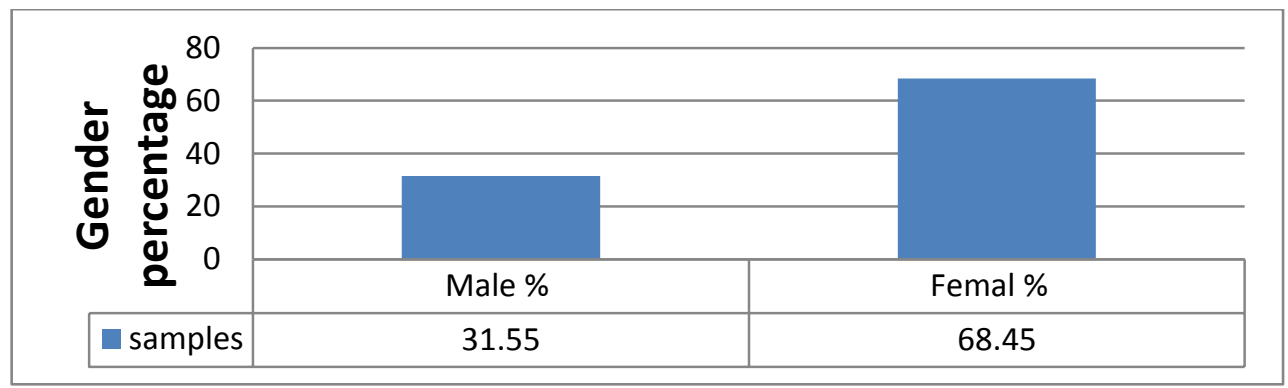

Fig (2): Total distribution of Samples according to gender.

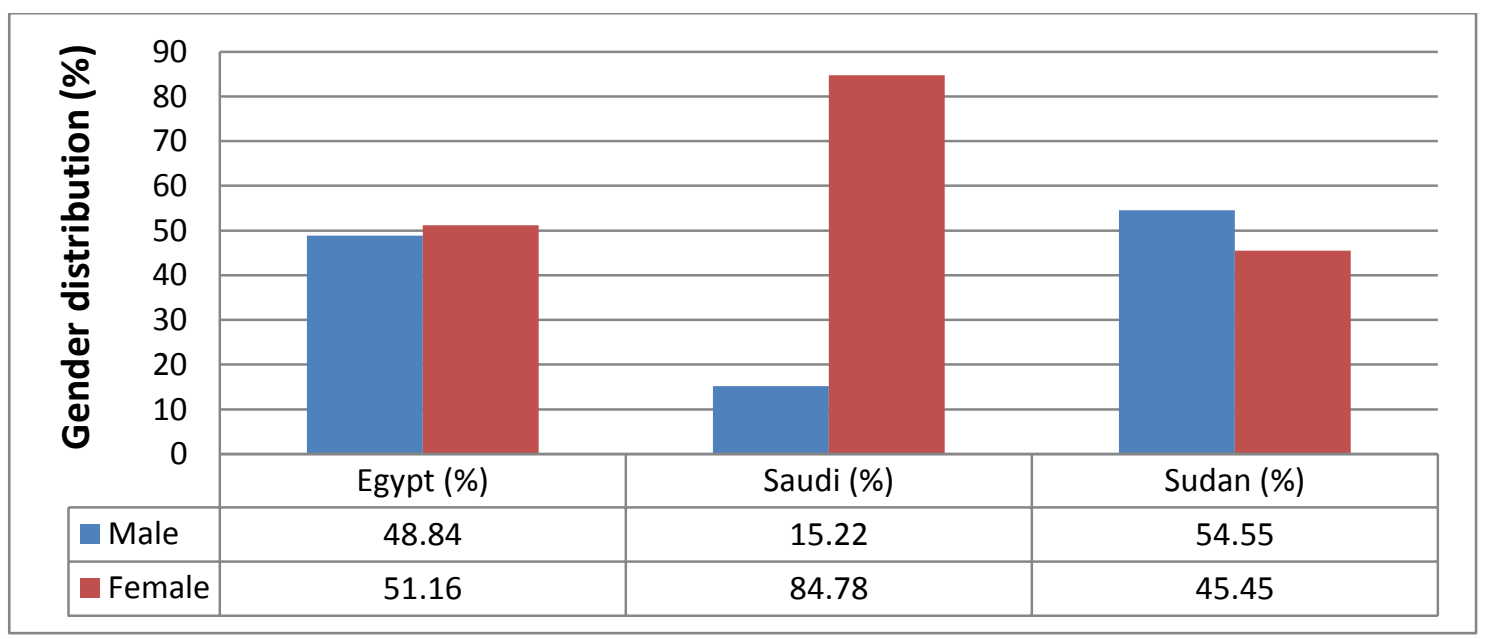

Fig (3): Percentage of samples distribution in three countries according to gender. 


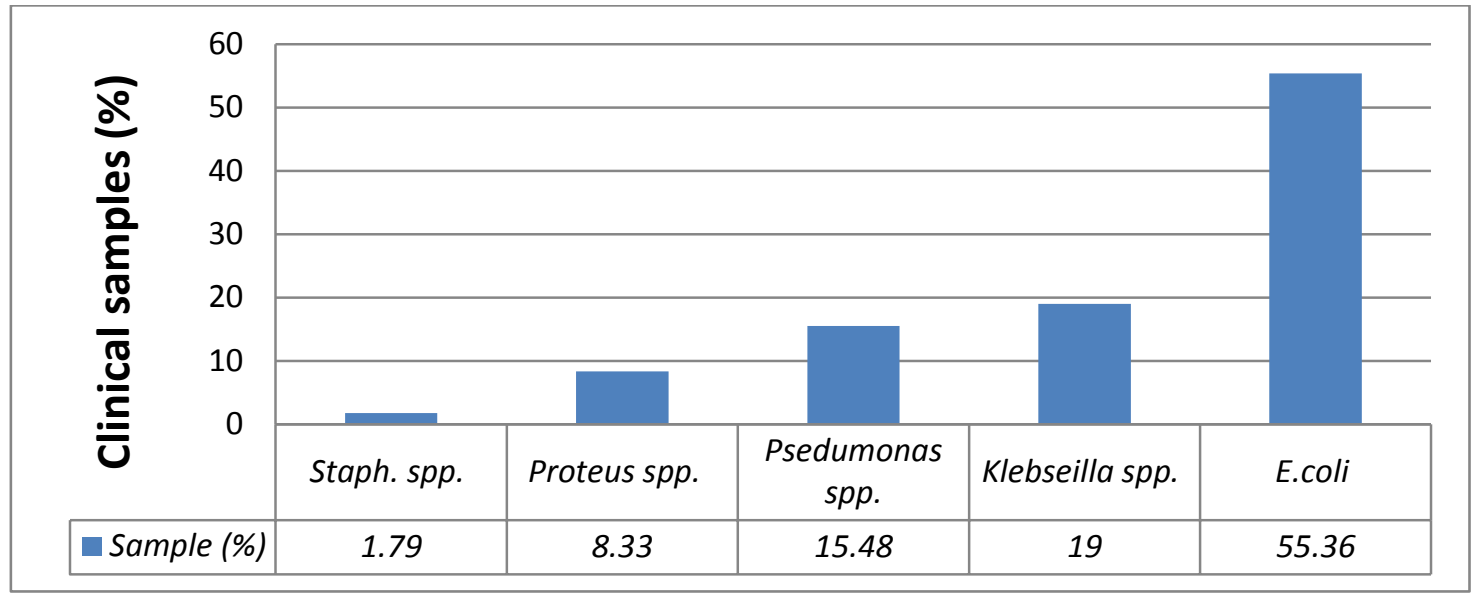

Fig (4): Total samples distribution according to organisms.

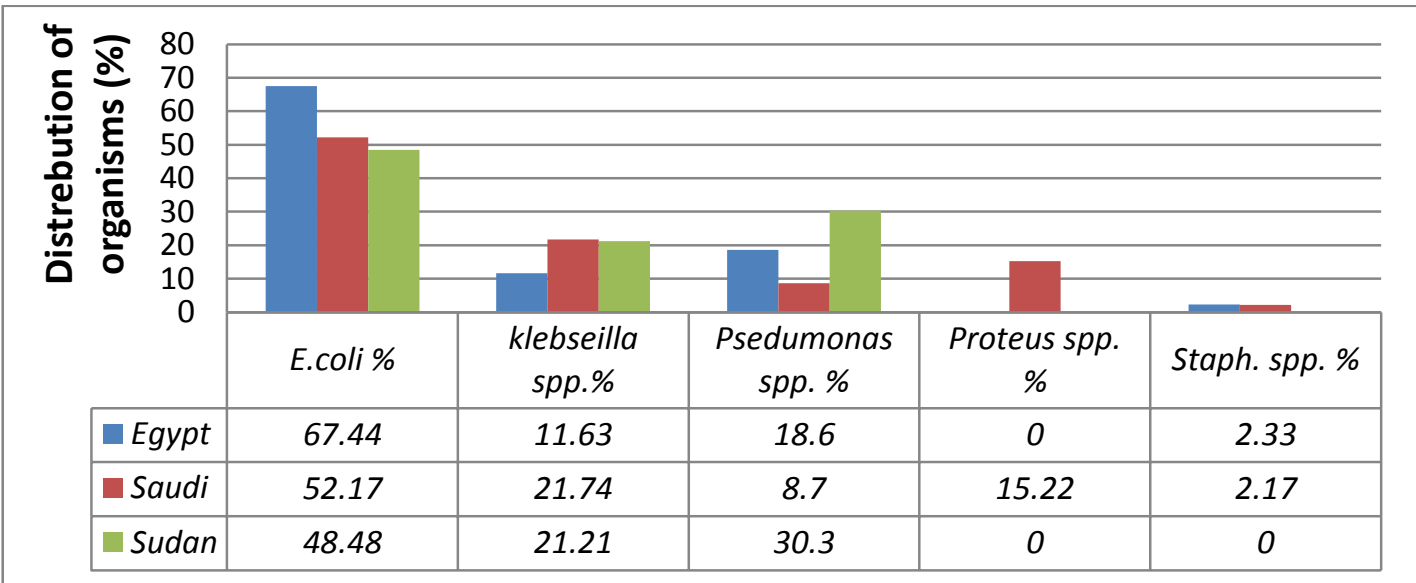

Fig (5): Organisms distribution among the three countries.

\begin{tabular}{|c|c|c|c|}
\hline \multirow{8}{*}{ 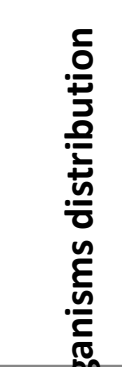 } & 70 & & \\
\hline & 60 & & \\
\hline & 50 & & \\
\hline & 40 & & \\
\hline & 30 & & \\
\hline & $\begin{array}{l}20 \\
10\end{array}$ & & \\
\hline & \multirow[t]{2}{*}{0} & & \\
\hline & & Male & Female \\
\hline \multicolumn{2}{|c|}{ E. छु } & 49.1 & 58.26 \\
\hline \multicolumn{2}{|c|}{ Klebseilla spp. \% } & 11.32 & 22.61 \\
\hline \multicolumn{2}{|c|}{ Psedumonas spp. \% } & 28.3 & 9.57 \\
\hline \multicolumn{2}{|c|}{ Proteus spp. \% } & 9.4 & 7.83 \\
\hline \multicolumn{2}{|c|}{ Staph. Spp \% } & 1.89 & 1.74 \\
\hline
\end{tabular}

Fig (6): Organisms distribution among two genders. 


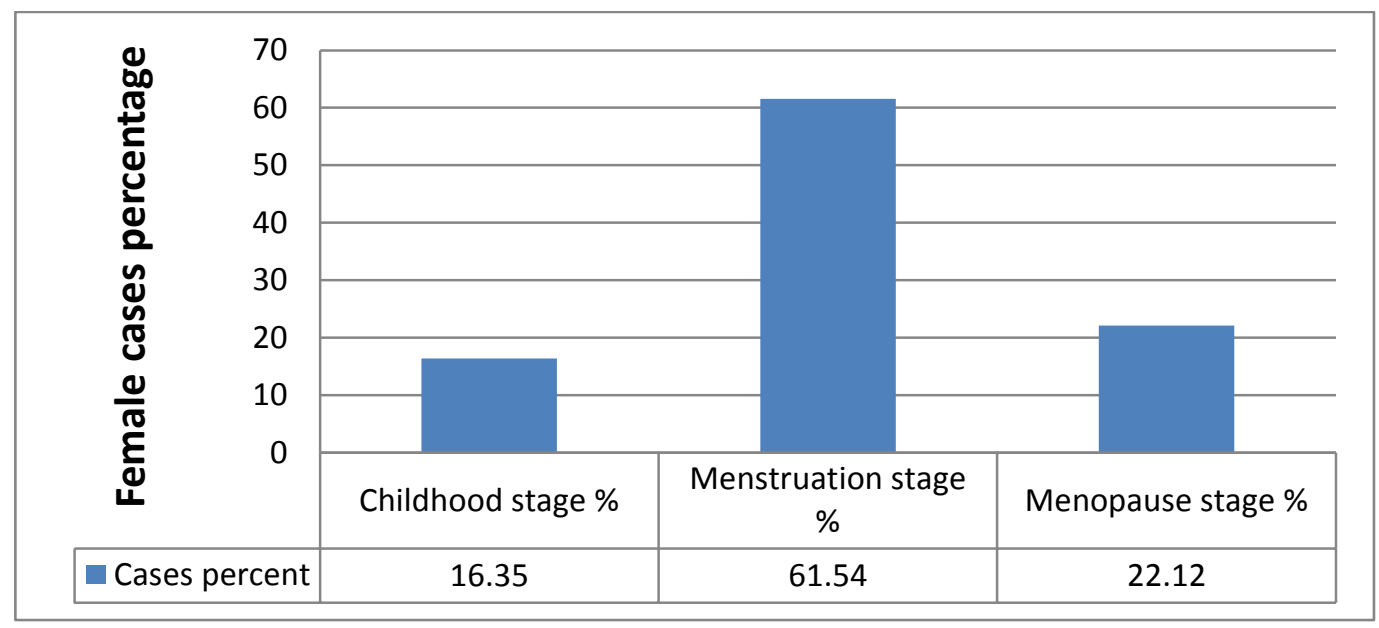

Fig (7): Female cases distribution according to age stage

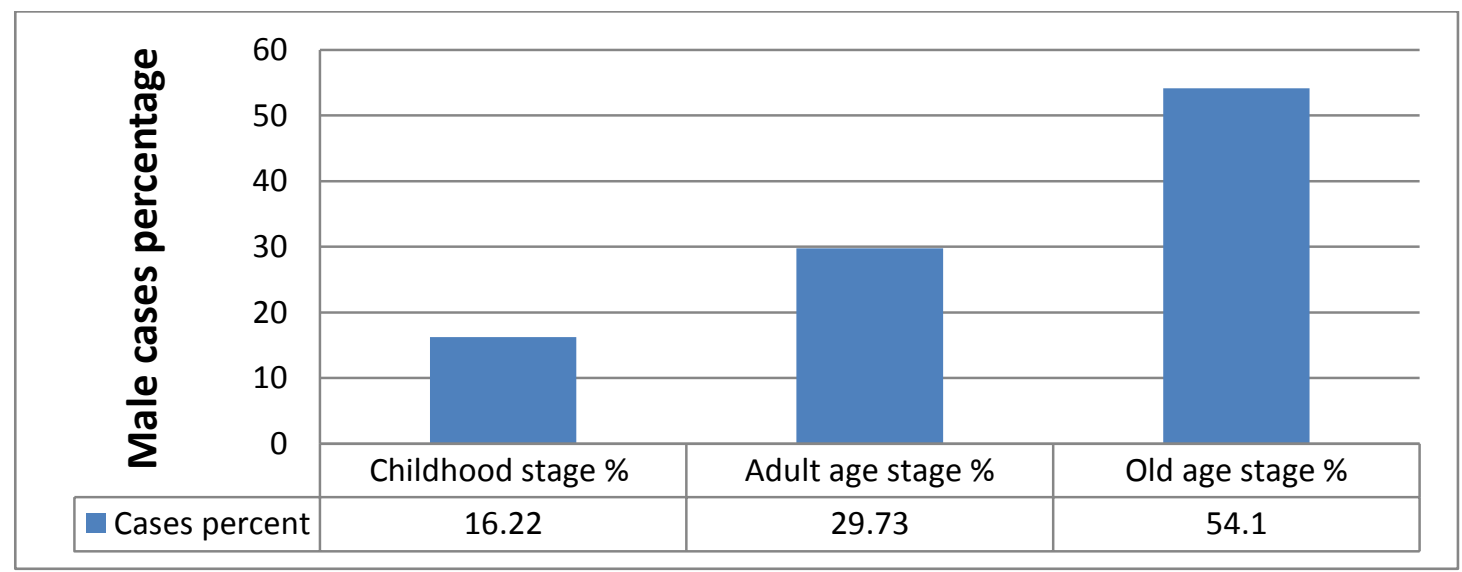

Fig (8): Male cases distribution according to age stage

\section{Discussion.}

Urinary tract infections (UTIs) are between the most common bacterial infections acquired in the community and in hospitals. In persons without anatomical or functional anomalies, UTIs are generally limited, but they tend to recur. Uropathogens have specialized properties, such as the production of binders and toxins that enable them to colonize and foray the urinary tract, and are transmitted between persons through personal contact and probably through food or water (Foxman, 2010) . Recurring and untreated UTIs lead to serious complications such as, urosepsis (Porat \& Kesler, 2020), early hypertension, weaken glomerular function, proteinuria and lastly, renal failure (Baghiani et al., 2013), Therefore, early detection and treatment of infection prevents these complications from occurring. In the present study, we reported that the number of women suffering from urinary tract infections are more than doubled the number of men affected. Generally, the biological as well as social differences 
between men and women have an effective role in the fact that women are more susceptible to microbial infection than men (Julie, 2004). As for urinary tract infection in particular, women are also more affected than men due to several factors, including that the urethra in women is much closer to the anus, as well as the low level of the estrogen hormone during menopause increases the risk of urinary tract infections due to the lack of protective vaginal flora (Griebling, 2007, Dielubanza \& Schaeffer, 2011). In addition, there is a relationship between urinary tract infections and vaginal atrophy that sometimes occurs after menopause (Goldstein et al., 2013). So studies reported that around 50-60\% of women may experience a UTI in their lifetime (Rahn, 2008), and repetition of around 25-30\% is noted in affected women (Finer \& Landau, 2004).

The previous studies have indicated that Gram-negative intestinal flora is the well-identified cause of most urinary tract infections worldwide (Flores-Mireles et al., 2015); this explains the greater percentage of both Escherichia and Klebsiella in women than men due to the proximity of their anus to the vaginal opening.

In our study all bacterial isolates were E. coli, Klebseilla spp., Pesudomonas spp., Proteus spp., and Staphylococcus spp. Studies reported that bacterial pathogens isolated from urine were Escherichia coli, Klebsiella pneumonia (Ronald, 2002, Amdekar et al., 2011, Stefaniuk et al., 2016, Beyene \& Tsegaye, 2011), Proteus spp. (Ronald, 2002, Amdekar et al., 2011, Schaffer \& Pearson 2015, Stefaniuk et al., 2016,), Staphylococcus spp. (Ronald, 2002, Beyene \& Tsegaye, 2011, Amdekar et al., 2011) and Pseudomonas aeruginosa (Ronald, 2002, Todar, 2006, Tumbarello et al., 2020). The study refer to the majority of isolates were Escherichia coli, followed by Klebsiella spp. and Pseudomonas spp., and three species were isolated from three countries unlike other species. In the world, the most common pathogen causing urinary tract infection is Escherichia coli (Samra et al., 2005, Abraham \& Miao, 2015, Tandogdu \& Wagenlehner, 2016), followed by Klebsiella pneumonia ( Cristea et al., 2017) Pseudomonas aeruginosa is the third most common pathogen-linked with hospitalacquired catheter-associated UTIs (Jarvis \& Martone, 1992, Sabharwal et al., 2014). In this study, Proteus spp. was isolated only from Saudi specimens. Other studies indicated that in a healthy people, Proteus accounts for $1 \%$ to $2 \%$ of all UTIs, while in hospitalacquired UTIs, Proteus accounts for 5\% (Jamil et al., 2019).

According to female age stages, in our study the menstruation age stage (from puberty until menopause) was involving the majority of cases, followed by postmenopausal stage, while cases in childhood stage were the least. In young sexually active women, sexual activity is the reason of 75-90\% of bladder infections, with the jeopardy of infection regarding to the frequency of sex. On the other hand, in postmenopausal women, sexual activity does not impact the risk of developing a UTI (Nicolle, 2008), with consideration that the mean age at menarche in girls is 13.9 years (FH \& RM, 2008, Al Alwan et al., 2015, Ali et al., 2011), and the mean age at menopause is 48 years (Sallam et al. 2006, AlDughaither et al., 2015, , Abdelwahed 2018, Saad et al., 2019). In contrast, this study showed that adult men older than 45 of age who suffer from UTIs were the majority, followed by adult men under the age of 45, while the incidence of male children were the lowest. Other studies have reported that the incidence of UTIs in adult men is younger than 45 years of ages is low and 
uncommon (Abarbanel et al., 2003, Tan \& Chlebicki, 2016,]. In elderly men, prostate disease causes urinary tract symptoms and urinary retention (Beveridge et al., 2011).

\section{Conclusion.}

Surveys and studies on infectious factors are considered as one of the most important epidemiological tools for tracking infectious diseases and predicting disease patterns, especially with regard to urinary tract infections for their wide spread and serious complications between the sexes at the global level. Therefore, the authors recommend following up on groups in which the infection rate was higher than others, such as non-childhood females, as well as men over the age of fifty, and taking necessary measures to limit the spread of infection among these. As well as limiting its repetition or neglect to avoid complications that may kill the patient.

\section{REFERENCES:}

Abarbanel, J., Engelstein, D., Lask, D., \&Livne, P. M. (2003). Urinary tract infection in men younger than 45 years of age: is there a need for urologic investigation?. Urology, 62(1), 27-29.

Abdelwahed Shams-Eldin, A. (2018). Knowledge, Attitude and Severity of Menopausal Symptoms among Women Attending Primary Health Care Centers in Cairo, Egypt. Al-Azhar Medical Journal, 47(2), 423-434.

Abraham, S. N., \& Miao, Y. (2015). The nature of immune responses to urinary tract infections. Nature Reviews Immunology, 15(10), 655.

Al Alwan, I. A., Ibrahim, A. A., Badri, M. A., Al Dubayee, M. S., \& Bin-Abbas, B. S. (2015).Decline in menarcheal age among Saudi girls. Saudi medical journal, 36(11), 1324.

AlDughaither, A., AlMutairy, H., \&AlAteeq, M. (2015). Menopausal symptoms and quality of life among Saudi women visiting primary care clinics in Riyadh, Saudi Arabia. International journal of women's health, 7, 645.

Alfred, B., \& Heidi, S. (2015). Microbiological Application. McGraw Hill Education.

Ali, A. A. A., Rayis, D. A., Mamoun, M., \& Adam, I. (2011).Age at menarche and menstrual cycle pattern among schoolgirls in Kassala in eastern Sudan. Journal of Public Health and Epidemiology, 3(3), 111-114.

Amdekar, S., Singh, V., \& Singh, D. D. (2011). Probiotic therapy: immunomodulating approach toward urinary tract infection. Current microbiology, 63(5), 484.

Baghiani Moghadam, M. H., Shojaeazadeh, D., Mohamadloo, A., Fallahzadeh, H., \& Ranjbary, M. (2013). Evaluation of preventive behaviors of UTI based on health belief model (HBM) in mothers with girls younger than 6 years old. Tolooebehdasht, 12(1), 78-88. 
Barber, A. E., Norton, J. P., Spivak, A. M., \&Mulvey, M. A. (2013). Urinary tract infections: current and emerging management strategies. Clinical infectious diseases, 57(5), 719-724.

Beveridge, L. A., Davey, P. G., Phillips, G., \& McMurdo, M. E. (2011).Optimal management of urinary tract infections in older people. Clinical interventions in aging, 6, 173.

Beyene, G., \&Tsegaye, W. (2011). Bacterial uropathogens in urinary tract infection and antibiotic susceptibility pattern in Jimma University Specialized Hospital, Southwest Ethiopia. Ethiopian Journal of Health Sciences, 21(2), 141-146.

Cheesbrough, M. (2006). District laboratory practice in tropical countries, part 2. Cambridge university press.

Coico, R. (2006).Gram staining. Current Protocols in Microbiology, (1), A-3C.

Cristea, O. M., Avrămescu, C. S., Bălășoiu, M.,Popescu, F. D., Popescu, F., \&Amzoiu, M. O. (2017). Urinary tract infection with Klebsiellapneumoniae in Patients with Chronic Kidney Disease. Current health sciences journal, 43(2), 137.

Dielubanza, E. J., \& Schaeffer, A. J. (2011). Urinary tract infections in women. Medical clinics, 95(1), 27-41.

FH, H., \& RM, S. (2008). Optimal age of sexual maturation in Egyptian children.

Finer, G., \& Landau, D. (2004).Pathogenesis of urinary tract infections with normal female anatomy. The Lancet infectious diseases, 4(10), 631-635.

Flores-Mireles, A. L., Walker, J. N., Caparon, M., \&Hultgren, S. J. (2015). Urinary tract infections: epidemiology, mechanisms of infection and treatment options. Nature reviews microbiology, 13(5), 269-284.

Foxman, B. (2010). The epidemiology of urinary tract infection. Nature Reviews Urology, 7(12), 653-660.

Gilbert, N. M., O'brien, V. P., Hultgren, S., Macones, G., Lewis, W. G., \& Lewis, A. L. (2013). Urinary tract infection as a preventable cause of pregnancy complications: opportunities, challenges, and a global call to action. Global advances in health and medicine, 2(5), 59-69.

Goldstein, I., Dicks, B., Kim, N. N., \&Hartzell, R. (2013).Multidisciplinary overview of vaginal atrophy and associated genitourinary symptoms in postmenopausal women. Sexual medicine, 1(2), 44-53.

Griebling, T. L. (2007).Urinary tract infection in women. Urologic diseases in America, 7, 587-619. 
Jamil, R. T., Foris, L. A., \& Snowden, J. (2019). Proteus mirabilis Infections.

Jarvis, W. R., \&Martone, W. J. (1992). Predominant pathogens in hospital infections. Journal of Antimicrobial Chemotherapy,29(suppl_A), 19-24.

Julie L. Gerberding (2004). Women and Infectious Diseases.Emerg Infect Dis. 2004 Nov; 10(11): 1965-1967.

MacConkey, A. T. (1900). Note on a new medium for the growth and differentiation of the Bacillus colicommunis and the Bacillus typhiabdominalis. Lancet, 156(4010), 20.

McLeod, J. W., Wheatley, B., \&Phelon, H. V. (1927). On some of the unexplained difficulties met with in cultivating the gonococcus: The part played by the amino-acids. British Journal of Experimental Pathology, 8(1), 25.

Muder, R. R., Brennen, C., Rihs, J. D., Wagener, M. M., Obman, A., Obman, A., \& Yu, V. L. (2006). Isolation of Staphylococcus aureus from the urinary tract: association of isolation with symptomatic urinary tract infection and subsequent staphylococcal bacteremia. Clinical infectious diseases, 42(1), 46-50.

Muñoz, P., Cercenado, E., Rodríguez-Créixems, M., Díaz, M. D., Vicente, T., \&Bouza, E. (1992). The CLED agar option in urine culture routine: a prospective and comparative evaluation. Diagnostic microbiology and infectious disease, 15(4), 287-290.

Nicolle, L. E. (2008). Uncomplicated urinary tract infection in adults including uncomplicated pyelonephritis. Urologic Clinics of North America, 35(1), 1-12.

Porat, A., \& Kesler, S. (2020). Urosepsis. In StatPearls [Internet]. StatPearls Publishing.

Rahn, D. D. (2008). Urinary tract infections: contemporary management. UrolNurs, 28(5), 333-341.

Ronald, A. (2002). The etiology of urinary tract infection: traditional and emerging pathogens. The American journal of medicine, 113(1), 14-19.

Saad, R. A., Elmukashfi, S. T. A., Saeed, A. M., \& Khalid, M. O. (2019).Evaluation of Serum Calcium, Phosphorus and Progesterone in Post-Menopausal Women in Khartoum State-Sudan. International Journal of Chinese Medicine, 3(2), 30.

Sabharwal, N., Dhall, S., Chhibber, S., \&Harjai, K. (2014). Molecular detection of virulence genes as markers in Pseudomonas aeruginosa isolated from urinary tract infections. International Journal of Molecular Epidemiology and Genetics, 5(3), 125. 
Sallam, H., Galal, A. F., \&Rashed, A. (2006). Menopause in Egypt: past and present perspectives. Climacteric, 9(6), 421-429.

Samra, K. S. S., Cenk, S., Horu, G. M. G., \&Beril, O. (2005). Increasing antimicrobial resistance of Escherichia coli isolates from community acquired UTI during 1998-2003. Manisa Turkey Japan. J Infect Dis, 58, 159-161.

Sandys, G. H. (1960). A new method of preventing swarming of Proteusspp. with a description of a new medium suitable for use in routine laboratory practice. Journal of Medical Laboratory Technology, 17(4), 224-33.

Schaffer, J. N., \& Pearson, M. M (2015).Proteus mirabilis and Urinary Tract Infections.Microbiol Spectr, 3(5).

Spector, W. S. (Ed.). (1961). Handbook of biological data. Saunders.

Stefaniuk, E., Suchocka, U., Bosacka, K., \&Hryniewicz, W. (2016).Etiology and antibiotic susceptibility of bacterial pathogens responsible for communityacquired urinary tract infections in Poland. European Journal of Clinical Microbiology \& Infectious Diseases, 35(8), 1363-1369.

Tan, C. W., \&Chlebicki, M. P. (2016).Urinary tract infections in adults. Singapore medical journal, 57(9), 485.

Tandogdu, Z., \&Wagenlehner, F. M. (2016).Global epidemiology of urinary tract infections. Current opinion in infectious diseases, 29(1), 73-79.

Thayer, J. D., \& Martin Jr, J. E. (1964).A selective medium for the cultivation of $N$. gonorrhoeae and N. meningitidis. Public health reports, 79(1), 49.

Todar, K. (2006). Todar's online textbook of bacteriology: University of WisconsinMadison Department of Bacteriology Madison.

Tumbarello, M., Raffaelli, F., Peghin, M., Losito, A. R., Chirico, L., Giuliano, G., ...\&Bassetti, M. (2020). Characterisation and risk-factor profiling of $P$. aeruginosa urinary tract infections: pinpointing those likely to be caused by multidrug-resistant strains. International Journal of Antimicrobial Agents, 105900. 


\title{
معدل انتشار عدوى المسالكك البولية وعلاقة مسببات الأمراض البكتيرية بالجنس والأعمار بين

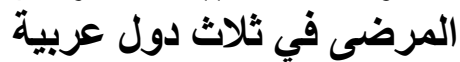

\author{
خالد صلاح محمد عزب*' ، محمد علي عبد الرحمن' ، حسين حسني الثيخ' ، محمد منصور سعد فرج ' \\ قسم النبات و الميكروبيولوجي - كلبة العلوم - جامعة الأزهر
}

khaedsalah@azhar.edu.eg : البريد الاكتروني للباحث الرئيسي *

الملخص:

يهدف هذا البحث إلى مسح دراسة وتوصيف عزلات مختلفة من عينات بول تم جمعها من دول مختلفة

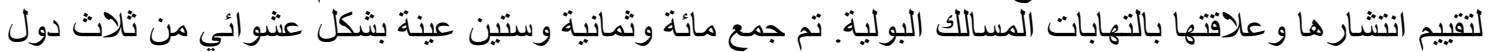

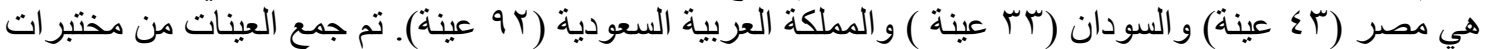

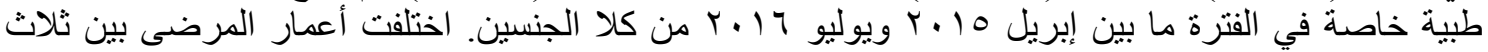

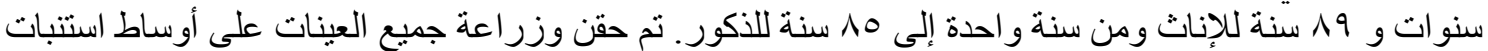

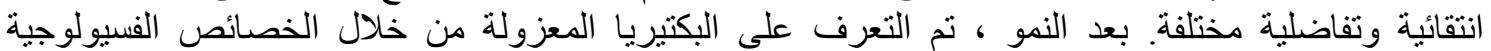

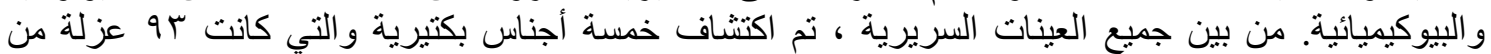

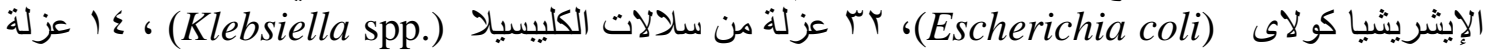

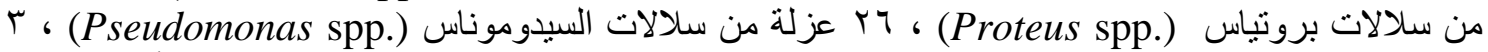

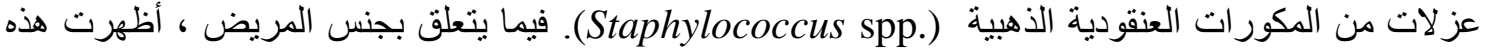

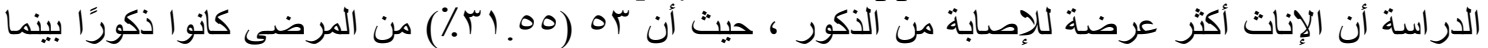

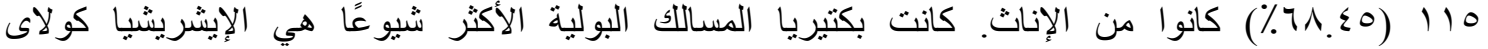
(Escherichia coli)

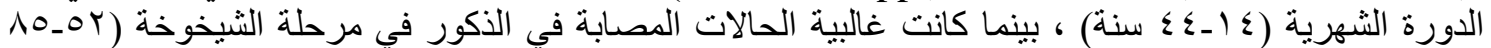

